\title{
IDENTIFICATION OF PHASE TRANSFORMATION MODEL FOR THE SIMULATION OF CONTROLLED COOLING OF BAINITIC STEEL TUBES
}

\begin{abstract}
JMAK (Johnson-Mehl-Avrami-Kolmogorov) equation was adapted to simulation of phase transformations during cooling of bainitic steel tubes. The model was identified on the basis of the results obtained from the JMatPro software. Numerical tests for various cooling schedules showed model's capability to predict a volume fraction of microstructure constituents of the tubes. The model was implemented into FE code for the simulation of tubes cooling. For the sake of the model capabilities, three cooling methods were considered: (i) free cooling in the air, (ii) cooling with the pressurised air, (iii) cooling with the water mist. Both symmetrical and asymmetrical cooling conditions were considered. The volume fractions of the tube's microstructure constituents were calculated for each cooling conditions.
\end{abstract}

Keywords: phase transformations, JMAK model, tubes of bainitic steels, numerical simulations of tubes cooling

\section{IDENTYFIKACJA MODELU PRZEMIAN FAZOWYCH DLA POTRZEB SYMULACJI KONTROLOWANEGO CHŁODZENIA RUR ZE STALI BAINITYCZNYCH}

\begin{abstract}
W artykule adaptowano model JMAK (Johnson-Mehl-Avrami-Kolmogorov) do symulacji numerycznej przemian fazowych $w$ procesie chłodzenia rur ze stali bainitycznych. Identyfikacje modelu przemian fazowych przeprowadzono na podstawie wyników obliczeń wykonanych za pomoca programu komputerowego JMatPro. Badania numeryczne, przeprowadzone dla różnych metod chłodzenia rur, pokazały możliwości obliczeniowe opracowanego modelu, które obejmuja przewidywania udziałów objętościowych składników mikrostruktury stali podczas chłodzenia po austenityzacji. Opracowany model numeryczny przemian fazowych implementowano w kodzie opartym na metodzie elementów skończonych (MES), symulującym proces chłodzenia rur. Obliczenia przeprowadzono dla następujacych warunków chłodzenia: (i) chłodzenie w spokojnym powietrzu, (ii) chłodzenie sprężonym powietrzem, (iii) chłodzenie mgła wodno-powietrzną. Dla każdego sposobu chłodzenia, obliczono udziały objętościowe składników mikrostruktury rur.
\end{abstract}

Stowa kluczowe: przemiany fazowe, model JMAK, rury ze stali bainitycznych, modelowanie numeryczne chłodzenia rur

\section{INTRODUCTION}

Problem of phase transformation modelling in bainitic steels has been thoroughly investigated and it is described in the scientific literature, see eg. works of Bhadeshia [1, 2]. Models of various complexity ranging from simple JMAK (Johnson-Mehl-Avrami-Kolmogorov) equation [3] to advanced phase field approach [4] were developed. On the other hand, connection of these models with FE models of thermal cycles during cooling of tubes is not addressed in the literature. Simulations of cooling of tubes focus on the calculations of temperature variations for applied cooling methods [5], without connection with the metallurgical models.

Authors have adapted JMAK equation to simulate cooling of fasteners [6] and rods [7]. Problem of connection of the JMAK model with the FE temperature calculations was solved following the algorithm presented in [8]. The main objective of the present work was application of this model to cooling of tubes during heat treatment. The particular objectives included: i) identification of the model for various tube steels, ii) numerical tests of the model for various cooling conditions, iii) implementation of the model into the finite element (FE) code and simulation of kinetics of phase transformations during controlled cooling of tubes.

\section{MODEL}

\subsection{FINITE ELEMENT MODEL OF HEAT TRANSFER}

Temperature field at the cross section of the tube was calculated by the finite element (FE) solution of the Fourier equation: 


$$
\nabla^{T}(k \nabla) T+\left(Q-c_{p} \rho \frac{\partial T}{\partial t}\right)=0
$$

where:

$T$ - temperature in ${ }^{\circ} \mathrm{C}$,

$k$ - thermal conductivity,

$c_{p}$ - specific heat,

$\rho$ - density,

$t$ - time.

Solution of equation (1) has to fulfil the following boundary condition:

$$
k \frac{\partial T}{\partial n}=\alpha\left(T-T_{a}\right)
$$

where:

$T_{a}$ - ambient temperature in ${ }^{\circ} \mathrm{C}$,

$n$ - unit vector normal to the surface,

$\alpha$ - heat transfer coefficient.

$Q$ in equation (1) is the heat generated during phase transformation per unit volume and is given by following equation:

$$
Q=\rho \Delta H \frac{d X}{d t}
$$

where:

$\Delta H$ - enthalpy change due to a phase transformation,

$d X / d t$-rate at which transformation proceeds.

Equation (1) is solved in a typical finite element manner [9]. Authors numerical solution is described in [10]. Finite element mesh used in calculations is shown in Figure 1. Points A, B and C, in which the results are presented, are shown in this figure.

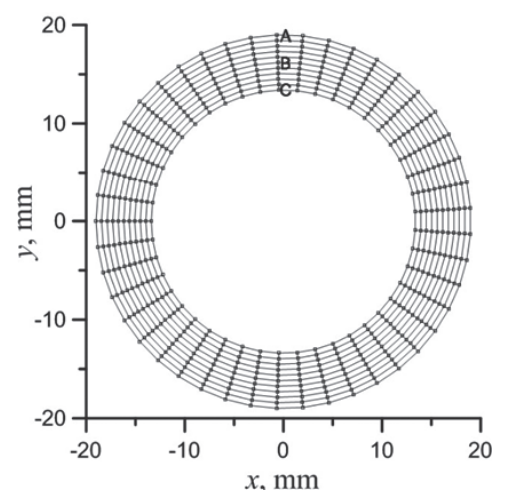

Fig. 1. Finite element mesh used in numerical calculations

Rys. 1. Siatka elementów skończonych zastosowana w obliczeniach numerycznych

Two steels with chemical composition given in Table 1, designed for the production of tubes, were investigated.

Thermophysical properties of these steels were determined using JMatPro software [11] and they are shown in Figure 2. Equations describing dependence of these properties on temperature are given in this figure, as well.

Selection of the heat transfer coefficient $(\alpha)$ for various cooling conditions is crucial for the accuracy of a)

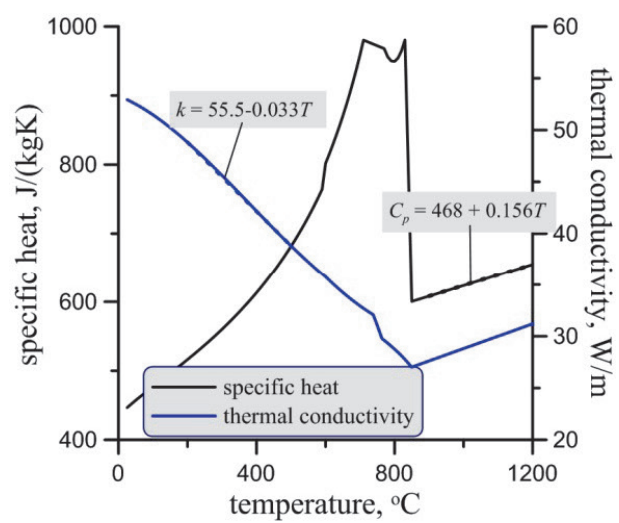

b)

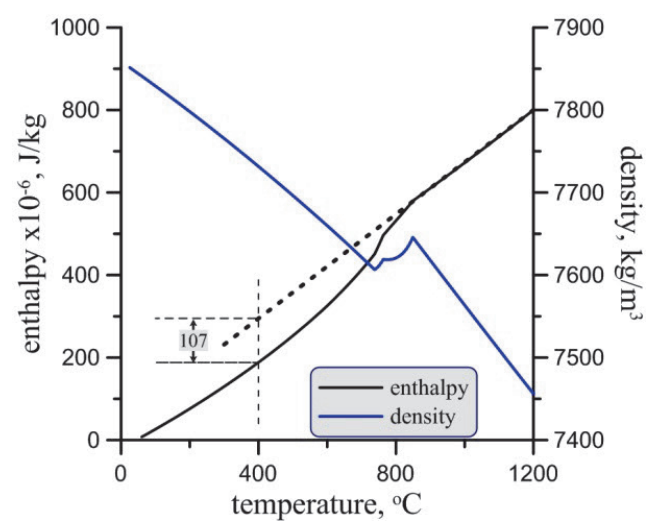

Fig. 2. Thermophysical properties of the tube steels $A$ and B calculated using JMatPro program

Rys. 2. Właściwości termofizyczne stali A i B na rury obliczone $z$ wykorzystaniem programu JMatPro

simulations. This coefficient, which has to account for both radiation and convection mechanisms, was determined using inverse analysis for the experimental data obtained during cooling of tubes at various conditions. The general radiation equation was used:

$$
q_{r}=\varepsilon \sigma\left(T_{K}^{4}-T_{K a}^{4}\right)
$$

where:

$q_{r}$ - heat flux due to radiation,

$\varepsilon$ - emissivity,

$\sigma=5.6703 \cdot 10^{-8}-$ Boltzman constant,

$T_{K}$ - temperature in $\mathrm{K}$,

$T_{K a}$ - ambient temperature in $\mathrm{K}$.

The radiative heat transfer coefficient $\left(\alpha_{r}\right)$ can be calculated by rearranging equation (4) as follows:

$$
\alpha_{r}=\varepsilon \sigma\left(T^{2}+T_{a}^{2}\right)\left(T-T_{a}\right)
$$

Emissivity $(\varepsilon)$ in equation (5) depends on the material and its temperature. Numerous publications dealing with determination of the emissivity were published, however, majority of them deal with other than metal forming processes (heating in the furnace, cooling of reactors, steel in fire etc). For steel cooled after hot forming the emissivity is in the range $0.3-1.1$ and it

Table 1. Chemical composition of the investigated tube steels, wt $\%$

Tabela 1. Skład chemiczny badanych rur w \% wag.

\begin{tabular}{|c|c|c|c|c|c|c|c|c|}
\hline & C & Mn & Si & Mo & Cr & Ni & Cu & Al \\
\hline Steel A & 0.13 & 0.48 & 0.42 & 0.2 & 0.84 & - & 0.2 & 0.004 \\
\hline Steel B & 0.25 & 0.5 & 0.7 & 0.2 & 1.2 & 0.2 & 0.2 & 0.008 \\
\hline
\end{tabular}


increases when the temperature decreases. The following relation was proposed in [12]:

$$
\varepsilon=1.2-0.5 T_{1000}
$$

where: $T_{1000}=T / 1000$.

In the present project the emissivity $(\varepsilon)$ for a cooling of tubes was introduced as a function of the temperature:

$$
\varepsilon=\varepsilon_{0}\left[1+0.925\left(1-T_{1000}\right)\right]
$$

where:

$\varepsilon_{0}$ - coefficient, which was determined on the basis of experiments.

Natural convection was simulated for free air cooling and forced convection was simulated for cooling with pressurised air. Natural convection is caused by buoyancy forces due to density differences caused by temperature variations in the cooling medium. During heating, the density change in the boundary layer will cause the fluid to rise and be replaced by cooler fluid that also will heat and rise. This continuing phenomenon is called free or natural convection. Boiling or condensing processes are also referred to as a convective heat transfer process.

The heat transfer per unit surface through convection was first described by Newton and the relation is known as the Newton's Law of Cooling. The amount of heat transferred due to convection $\left(q_{c}\right)$ depends on type of media, Prandtl Number (Pr), Grashof Number $(G r)$ and other flow and temperature dependent properties. The Prandtl Number is a dimensionless number approximating the ratio of momentum diffusivity (kinematic viscosity) to thermal diffusivity, and can be expressed as:

$$
\operatorname{Pr}=\frac{\eta c_{p}}{k}
$$

where:

$\eta$ - absolute or dynamic viscosity.

Grashof number is a dimensionless parameter used in the correlation of heat and mass transfer due to thermally induced natural convection at a solid surface immersed in a fluid. The significance of the Grashof number is that it represents the ratio between the buoyancy force due to spatial variation in fluid density (caused by temperature differences) to the restraining force due to the viscosity of the fluid. It is defined as:

$$
G r=\frac{g L^{3} \rho_{p}^{2} \beta}{\eta^{2}}
$$

where:

$g$ - acceleration due to gravity,

$c_{p}$ - specific heat,

$L$ - representative dimension,

$\beta=0.003661-$ thermal expansion of fluid,

$\rho_{p}=1.293$.

The convective heat transfer coefficient for natural convection depends on the product of Prandtl Number and Grashof Number, as follows:

- for $\operatorname{Pr} G r<0.5$

$$
\alpha_{c n}=0.3022 \exp \left(0.3416 T_{1000}\right)\left[\frac{\left(T-T_{a}\right)}{L^{5}}\right]^{0.125}
$$

- for $0.5<\operatorname{Pr} G r<2 \cdot 10^{7}$

$\alpha_{c n}=\left[0.3211+1.0804 \exp \left(-0.774 T_{1000}\right)\right]\left[\frac{\left(T-T_{a}\right)}{L}\right]^{0.25}$
- for $\operatorname{Pr} G r>2 \cdot 10^{7}$

$\alpha_{c n}=\left[0.4958+1.5745 \exp \left(-2.844 T_{1000}\right)\right]\left(T-T_{a}\right)^{1 / 3}$

Forced convection has to be considered when cooling in the air under pressure is applied. Effect of the cooling air velocity $(v)$ is introduces using the following coefficient:

$$
\zeta=11764 L v
$$

where:

$L$ - characteristic dimension of the cooled surface, $\mathrm{m}$.

The contribution of the forced convection to the heat transfer coefficient depends on the coefficient $(\zeta)$, as follows:

$$
\begin{gathered}
\alpha_{c f}=\beta_{1} \sqrt{\zeta} \text { for } \zeta \leq 10^{5} \\
\alpha_{c f}=\beta_{2}\left(0.037 \zeta^{0.8}-871\right) \text { for } \zeta>10^{5}
\end{gathered}
$$

where:

$\beta_{1}, \beta_{2}$-coefficients, which were determined on the basis of experiments.

The convective heat transfer coefficient accounting for the forced convection is:

$$
\alpha_{c}=\alpha_{c n}+\frac{0.055 \alpha_{c f}}{L}
$$

where:

$L$ - characteristic dimension of the cooled surface, $\mathrm{m}$.

The total heat transfer coefficient in equation (2) is a sum of radiation and convection:

$$
\alpha=\alpha_{r}+\alpha_{c}
$$

The heat transfer coefficients were identified and validated be comparison of predictions with the measurements during cooling of the tube in the laboratory conditions. The following values of the coefficients used for the adaptation of the model were obtained: $\beta_{1}=0.56$; $\beta_{2},=0.8879 ; \varepsilon_{0}=0.7$ for the outer surface; $\varepsilon_{0}=0.35$ for the inner surface. Convection heat transfer coefficient for cooling by the water mist $\left(\alpha_{c w}\right)$ was determined using inverse analysis for the experimental data and the following equation was obtained:

$$
\alpha_{c w}=800\left[1-1.01\left(1-T_{1000}\right)^{1 / 4}\right]
$$

where:

$L$ - characteristic dimension of the cooled surface, $\mathrm{m}$.

Selected result of the model validation is presented in Figure 3. Cooling of the tube with diameter of $32 \mathrm{~mm}$ and wall thickness of $4.2 \mathrm{~mm}$ was considered. Free cooling in the air, cooling with the pressurised air and cooling with the water mist were considered. Good agreement between measurements and calculations was obtained. The largest discrepancy between calculated and measured cooling curve is observed in the temperature range of ferritic and bainitic transformation.

A possible reason for the observed discrepancy is connected to the fact that the JMatPro program generates only approximate characterization of phase transformations kinetics. Therefore, the model will be validated in the future using the results of the phase transformations study which is currently under way. 


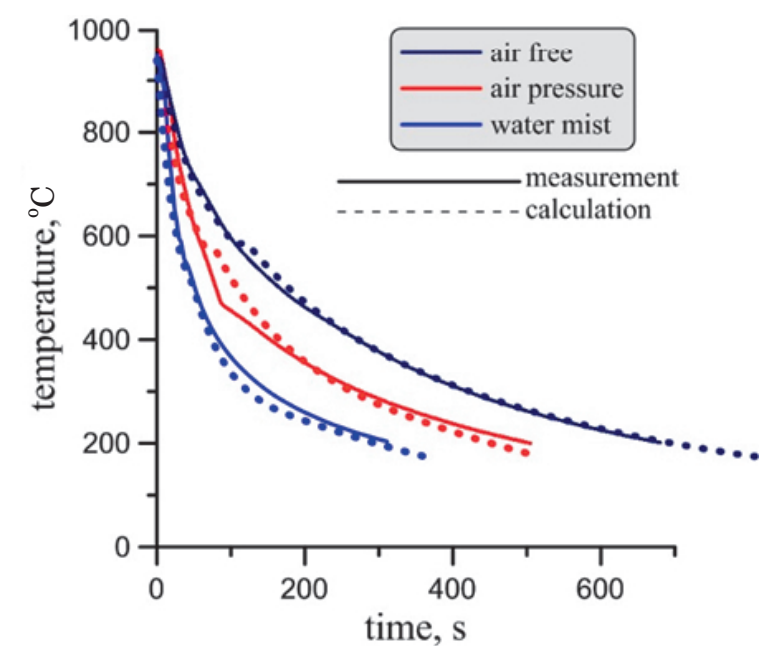

Fig. 3. Comparison of measured and calculated temperatures during cooling of tube using various coolants

Rys. 3. Porównanie zmierzonych i obliczonych zmian temperatury rur chłodzonych $\mathrm{z}$ wykorzystaniem różnych mediów chłodzących

\subsection{PHASE TRANSFORMATION MODEL}

Two phase transformation model is an upgrade of the JMAK (Johnson-Mehl-Avrami-Kolmogorov) equation. The model is described in earlier publication [13] and only main equations are repeated blow. JMAK equation adapted to the phase transformation has the form:

$$
X=1-\exp \left(-k t^{n}\right)
$$

where:

$$
\begin{aligned}
& n \text {-Avrami exponent, } \\
& k \text {-coefficient. }
\end{aligned}
$$

The following upgrades of this equation were introduced in the present work [13]:

- Avrami coefficient $n$ is assumed constant for each transformation (the first row in Table 2).

- Coefficient $k$ for ferrite, pearlite and bainite transformations was introduced as a function of temperature, as shown in [12]. Modified Gauss function was used for the ferrite transformation [14]. Nose of this function is located at the temperature of maximum rate of the transformation. Exponential functions were used for pearlite and bainite transformations [13], see the second row in Table 2.

- Using Gauss function for $k_{f}$ does not require the incubation time. It is assumed that ferrite transformation begins when $5 \%$ of ferrite is predicted by equation (16).

- Calculations of carbon concentration in the austenite during both ferrite and bainite transformations were added. In consequence prediction of the occurrence of the retained austenite became possible. Equations describing the incubation time for pearlite and bainite are given in the third row in Table 2.

- The $T_{0}$ temperature concept was added [2]. The $T_{0}$ curve is the locus of points on the temperature vs. carbon concentration plot where austenite and ferrite of the same chemical composition have identical free energies. This concentration is a boundary condition for calculation of the carbon distribution in the austenite using diffusion model.

- Relation of the kinetics of phase transformation on the austenite grain size was introduced into the model.

Main equations in the model are given in Table 2. Notation in this table: $D$ - austenite grain size, $T-$ temperature, in ${ }^{\circ} \mathrm{C}, T_{K}$ - temperature in $\mathrm{K}, n_{f}, n_{p}, n_{b}$, - coefficient $n$ in equation (16) for ferrite, pearlite and bainite, respectively, $k_{f}, k_{p}, k_{b}$, - coefficient $k$ in equation (16) for ferrite, pearlite and bainite, respectively. Remaining equations describe start temperatures in ${ }^{\circ} \mathrm{C}$ for bainite $\left(B_{s}\right)$ and martensite $\left(M_{s}\right)$, volume fraction of martensite $\left(F_{m}\right)$ and equilibrium carbon concentrations at the austenite-ferrite $\left(c_{\gamma \alpha}\right)$ and at the austenitecementite $\left(c_{\gamma \beta}\right)$ boundaries:

$$
\begin{gathered}
B_{s}=a_{20}-425[\mathrm{C}]-42.5[\mathrm{Mn}]-31.5[\mathrm{Ni}] \\
M_{s}=a_{20}-a_{26} c_{\gamma}
\end{gathered}
$$

$$
F_{m}=\left(1-F_{f}-F_{p}-F_{b}\right)\left\{1-\exp \left[-a_{27}\left(M_{s}-T\right)\right]\right\}
$$

where:

$F_{f}, F_{p}, F_{b}, F_{m}$-volume fractions of ferrite, pearlite, bainite and martensite, respectively, calculated with respect to the whole volume of the material.

Equation (16) combined with the Scheil additivity rule [15] allows to calculate changes of volume fraction of the new phase during transient state between the two equilibrium states. Equilibrium carbon concentrations at the austenite-ferrite $\left(c_{\gamma \alpha}\right)$ and austenitecementite $\left(c_{\gamma \beta}\right)$ interfaces are calculated from the following equations:

$$
c_{\gamma \alpha}=c_{\gamma \alpha 0}+c_{\gamma \alpha 1} T c_{\gamma \beta}=c_{\gamma \beta 0}+c_{\gamma \beta 1} T
$$

Details of the numerical solution of this phase transformation model are given in $[12,13]$. Accounting for changes of carbon concentration in the austenite during bainitic transformation is an important upgrade of the JMAK model. The current average carbon content in the austenite during bainitic transformation is described by the following equation:

Table 2. Main equations in the phase transformation model

Tabela 2. Podstawowe równania modelu przemian fazowych

\begin{tabular}{|c|c|c|}
\hline Ferrite & Pearlite & Bainite \\
\hline$n_{f}=a_{4}$ & $n_{p}=a_{16}$ & $n_{b}=a_{24}$ \\
\hline$k_{f}=\frac{a_{5}}{D} \exp \left[-\left(\frac{\left.\left|T-A_{e 3}-\frac{400}{D}+a_{6}\right|\right)^{a_{8}}}{a_{7}}\right]\right.$ & $k_{p}=a_{15} D^{a_{4}}$ & $k_{b}=a_{23} \exp \left[\left(\frac{T-a_{21}}{a_{22}}\right)^{2}\right]$ \\
\hline- & $\tau_{P}=\frac{a_{9} D^{a_{3}}}{\left(A_{e 1}-T\right)^{a_{11}}} \exp \left(\frac{a_{10}}{R T_{K}}\right)$ & $a_{b}=\frac{a_{17}}{\left(B_{S}-T\right)^{a_{19}}} \exp \left(\frac{a_{18}}{R T_{K}}\right)$ \\
\hline
\end{tabular}


Table 3. Coefficients in the phase transformation model for the investigated steels

Tabela 3. Współczynniki modelu przemian fazowych wyznaczone dla stali będących przedmiotem badań

\begin{tabular}{|c|c|c|c|c|c|c|c|c|c|c|c|c|c|}
\hline \multirow{4}{*}{ Steel A } & $a_{3}$ & $a_{4}$ & $a_{5}$ & $a_{6}$ & $a_{7}$ & $a_{8}$ & $a_{9}$ & $a_{10}$ & $a_{11}$ & $a_{12}, a_{13}$ & $a_{14}$ & $a_{15}$ & $a_{16}$ \\
\hline & 0.426 & 1.038 & 0.181 & 72.07 & 1344 & 3.44 & 27.66 & 16.39 & 0.002 & 0 & 0 & 2.21 & 0.051 \\
\hline & $a_{17}$ & $a_{18}$ & $a_{19}$ & $a_{20}$ & $a_{21}$ & $\boldsymbol{a}_{22}$ & $a_{23}$ & $a_{24}$ & $a_{25}$ & $a_{26}$ & $a_{27}$ & $a_{28}$ & $a_{29}$ \\
\hline & 6.56 & 65.02 & 2.5 & 670.9 & 0.026 & 0.028 & 0.376 & 2.028 & 735.6 & 2160 & 0.011 & 0.998 & 0.269 \\
\hline \multirow{4}{*}{ Steel B } & $a_{3}$ & $a_{4}$ & $a_{5}$ & $a_{6}$ & $a_{7}$ & $a_{8}$ & $a_{9}$ & $a_{10}$ & $a_{11}$ & $a_{12}, a_{13}$ & $a_{14}$ & $a_{15}$ & $a_{16}$ \\
\hline & 0.658 & 2.885 & 0.003 & 339.7 & 81.4 & 2.817 & 0.188 & 152.8 & 3.16 & 0 & 0.084 & 0.507 & 0.309 \\
\hline & $a_{17}$ & $a_{18}$ & $a_{19}$ & $a_{20}$ & $\boldsymbol{a}_{21}$ & $\boldsymbol{a}_{22}$ & $a_{23}$ & $a_{24}$ & $a_{25}$ & $\boldsymbol{a}_{26}$ & $a_{27}$ & $a_{28}$ & $a_{29}$ \\
\hline & 5.81 & 33.69 & 0.9 & 704.1 & 0.065 & 0.063 & 0.363 & 1.217 & 568 & 716.6 & 0.011 & 0.998 & 0.102 \\
\hline
\end{tabular}

a)

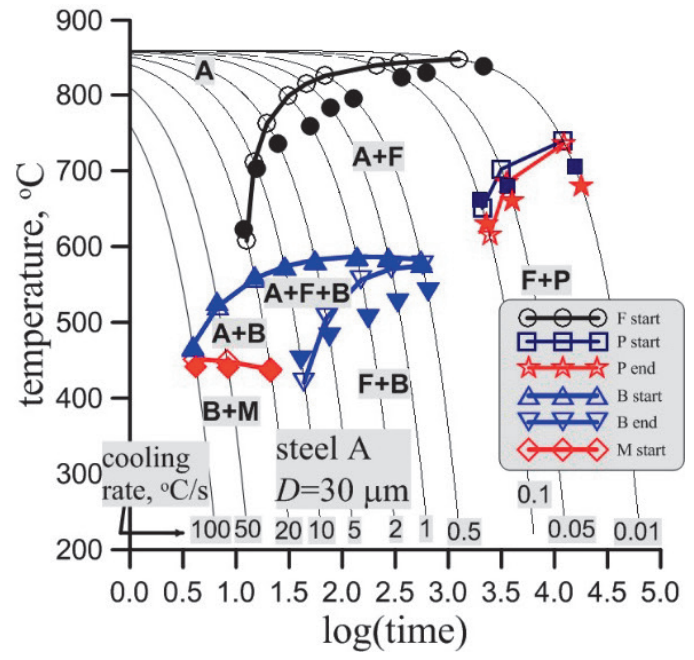

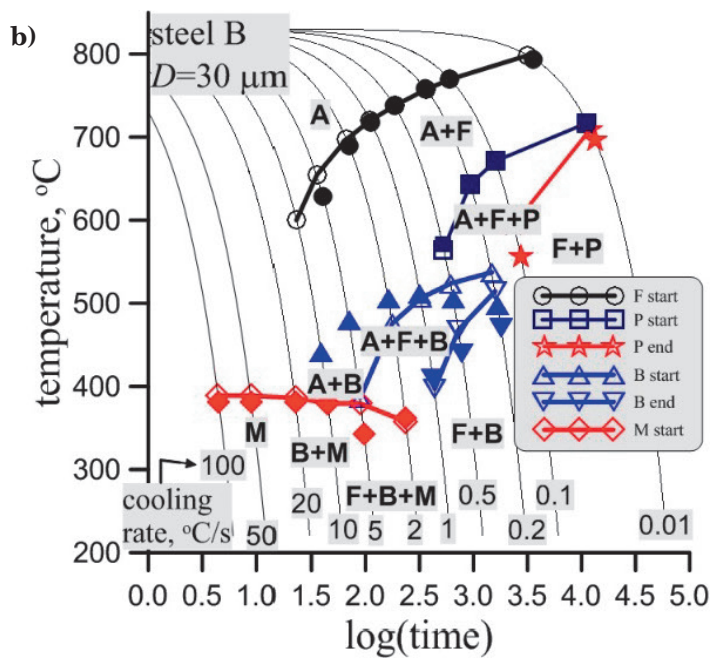

b)

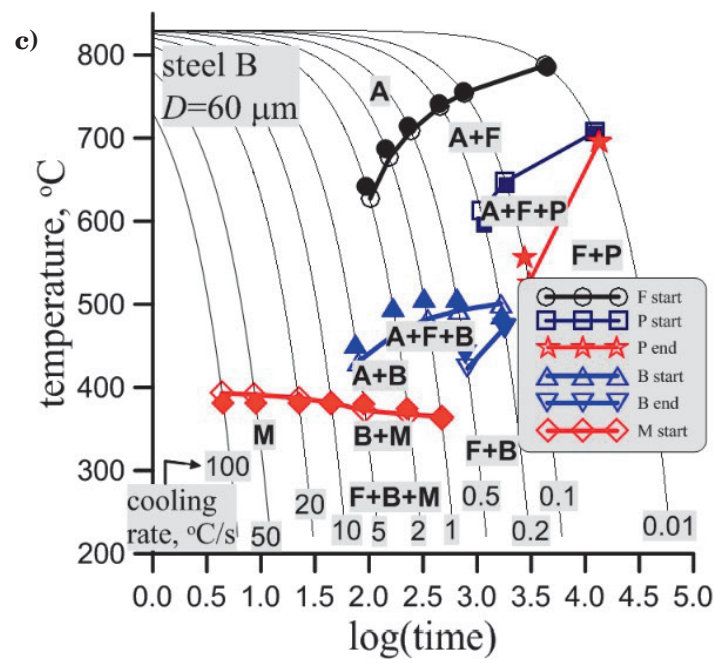

Fig. 4. Comparison of the transformation start and end temperatures calculated by the model (open symbols) and determined using JMatPro software (filled symbols): a) steel $A, D=30 \mu \mathrm{m}$; b) steel $B, D=30 \mu \mathrm{m}$; c) steel B, $D=60 \mu \mathrm{m}$. D is austenite grain size

Rys. 4. Porównanie wartości temperatur początku i końca przemian fazowych obliczonych za pomocą opracowanego modelu (otwarte symbole) oraz obliczonych za pomoca programu JMatPro (pełne symbole): a) stal A, D= $30 \mu \mathrm{m} ; \mathrm{b}$ ) stal B, D=30 $\mu \mathrm{m}$; c) stal B, D = $60 \mu \mathrm{m}$. D oznacza wielkość ziarna austenitu

$$
c_{\gamma}=\frac{\left[c_{0}-\left(F_{f}+\frac{F_{b}}{1-p}\right) c_{\alpha}\right]}{1-F_{f}-\frac{F_{b}}{1-p}}
$$

In equation (21) $p$ represents probability that a new platelet of the bainitic ferrite forms in a close neighbourhood of the existing one and its diffusion field is constrained by this neighbour. This probability is well explained in [16] and the details of the numerical solu- tion of the present model are given in [7]. The whole model contains 30 coefficients, which are grouped in the vector a. These coefficients were determined using inverse analysis of the data generated by the JMatPro software. Details of the inverse algorithm are given in [13]. Values of coefficients determined for the investigated steels are given in Table 3. Model with optimal coefficients was validated and the results are presented in Figure 4. Reasonably good accuracy of the model was obtained. 


\section{RESULTS}

\subsection{NUMERICAL TESTS OF THE MODEL}

Numerical tests comprised simulations of various cooling strategies. The first set of the tests was focused on a comparison of the kinetics of transformation for different cooling schedules, different steels and different grain sizes. The calculations started at austenitizing temperature of $900^{\circ} \mathrm{C}$. The selected results are presented in Figure 5-7. Kinetics of transformation for fast cooling $\left(30^{\circ} \mathrm{C} / \mathrm{s}\right)$ of steel B to temperatures of $460^{\circ} \mathrm{C}$, $430^{\circ} \mathrm{C}$ and $400^{\circ} \mathrm{C}$ followed by slow cooling $\left(0.5^{\circ} \mathrm{C} / \mathrm{s}\right)$ is presented in Figure 5. The predicted microstructure contains only martensite for $400^{\circ} \mathrm{C}$, only bainite for $460^{\circ} \mathrm{C}$ and mixture of bainite and martensite for $430^{\circ} \mathrm{C}$.

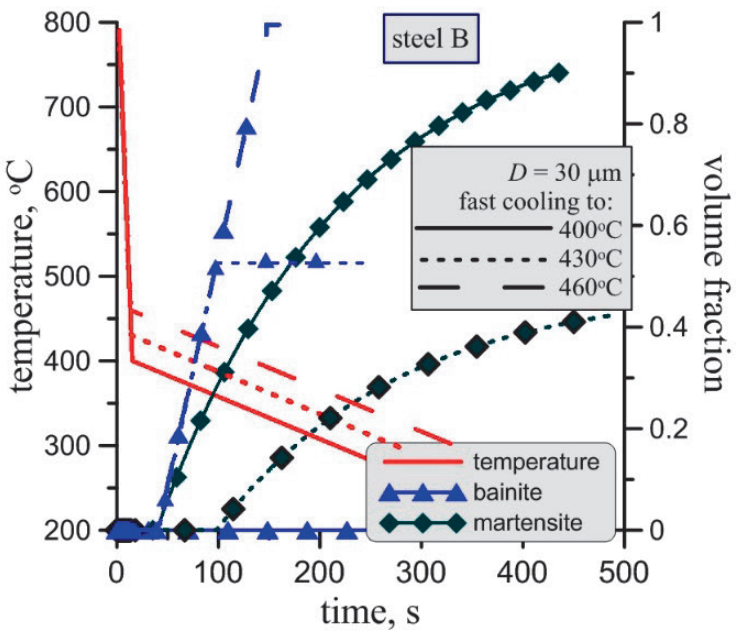

Fig. 5. Kinetics of phase transformations for fast cooling $\left(30^{\circ} \mathrm{C} / \mathrm{s}\right)$ to various temperatures followed by slow cooling $\left(0.5^{\circ} \mathrm{C} / \mathrm{s}\right)$

Rys. 5. Kinetyka przemian fazowych dla szybkiego chłodzenia $\left(30^{\circ} \mathrm{C} / \mathrm{s}\right)$ do różnych temperatur $\mathrm{z}$ następującym wolnym chłodzeniem z szybkością $\left(0,5^{\circ} \mathrm{C} / \mathrm{s}\right)$

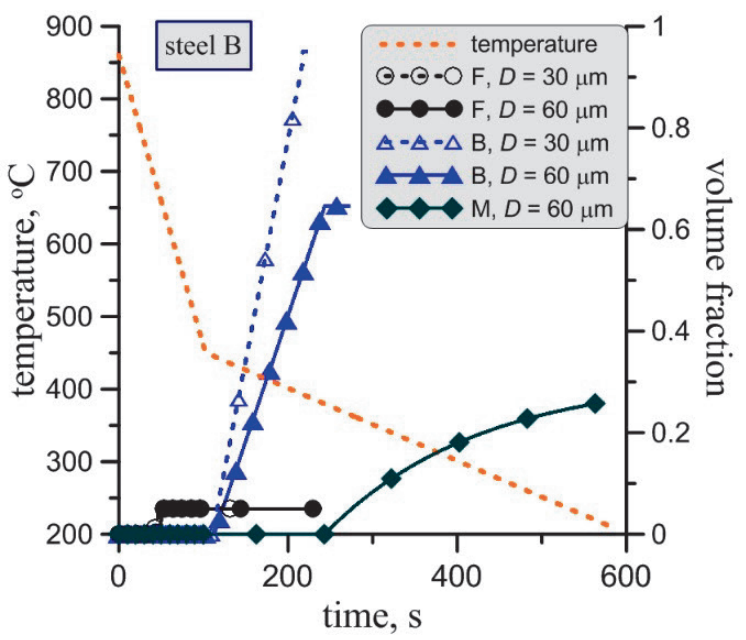

Fig. 6. Kinetics of phase transformations for cooling with the rate of $4^{\circ} \mathrm{C} / \mathrm{s}$ to the temperature of $450^{\circ} \mathrm{C}$ followed by slow cooling $\left(0.5^{\circ} \mathrm{C} / \mathrm{s}\right)$ obtained for various austenite grain size; ( F - ferrite, B - bainite, M - martensite)

Rys. 6. Kinetyka przemian fazowych podczas chłodzenia z szybkościa $4^{\circ} \mathrm{C} / \mathrm{s}$ do temperatury $450^{\circ} \mathrm{C}$, po którym następowało chłodzenie z szybkością $0,5^{\circ} \mathrm{C} / \mathrm{s}$ wyznaczona dla różnych wielkości ziarna austenitu (F - ferryt, B - bainit, M - martenzyt)
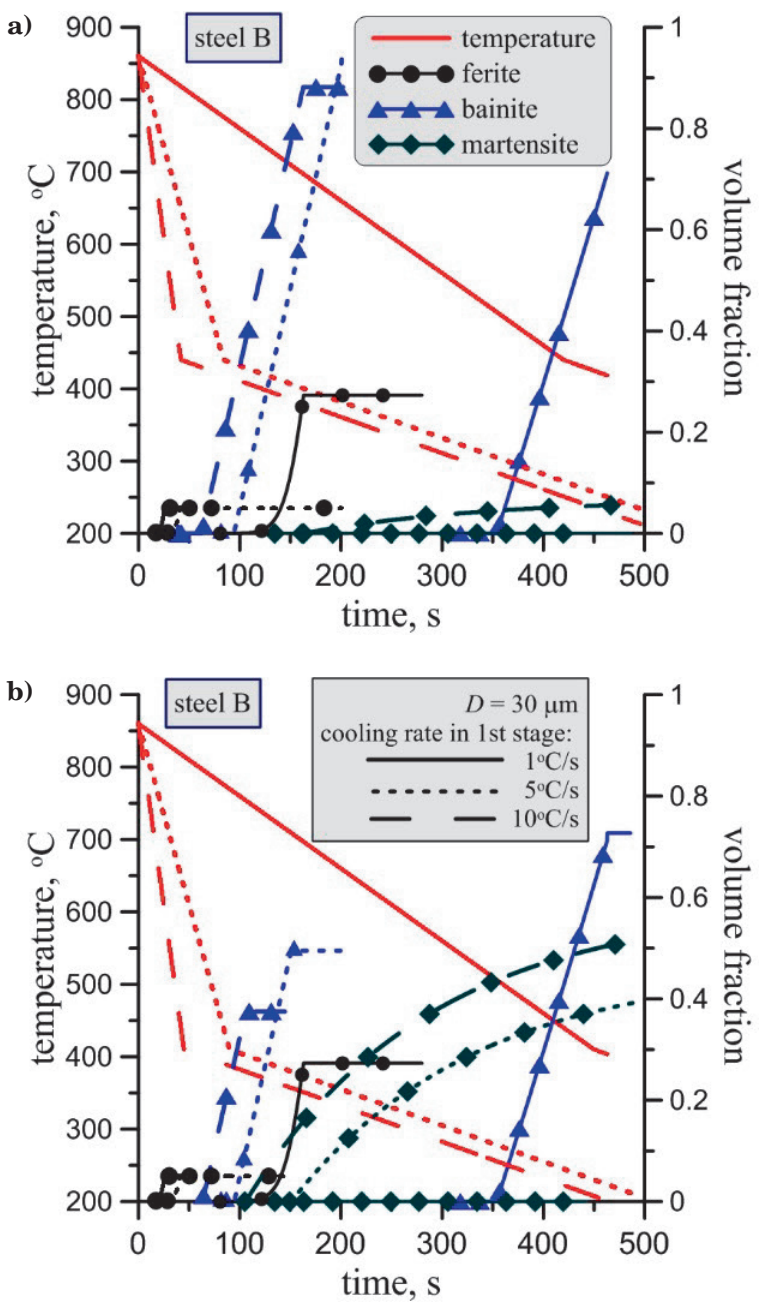

Fig. 7. Kinetics of phase transformations for cooling with various cooling rates to the temperature: $440^{\circ} \mathrm{C}$ (a) and $410^{\circ} \mathrm{C}(\mathrm{b})$, followed by slow cooling $\left(0.5^{\circ} \mathrm{C} / \mathrm{s}\right)$. Meaning of symbols and lines is the same on both plots

Rys. 7. Kinetyka przemian fazowych podczas chłodzenia

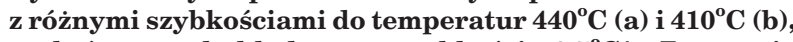
po którym stal chłodzono $\mathrm{z}$ szybkością $0,5^{\circ} \mathrm{C} / \mathrm{s}$. Znaczenie linii i symboli jest takie samo dla obu rysunków

The effect of the grain size is shown in Figure 6, where results for cooling with the rate of $4^{\circ} \mathrm{C} / \mathrm{s}$ to temperature of $450^{\circ} \mathrm{C}$ followed by slow cooling $\left(0.5^{\circ} \mathrm{C} / \mathrm{s}\right)$ are presented. It is seen that decrease of the grain size accelerates both ferrite and bainite transformations. In all figures, the following notation is used: $\mathrm{F}$ - ferrite, $\mathrm{B}$ - bainite, $\mathrm{M}$ - martensite.

Kinetics of transformation for cooling with various cooling rates to the temperature $440^{\circ} \mathrm{C}$ and $410^{\circ} \mathrm{C}$ followed by slow cooling $\left(0.5^{\circ} \mathrm{C} / \mathrm{s}\right)$ is shown in Figure 7 . Ferrite and bainite was predicted for slower cooling to higher temperature $\left(1^{\circ} \mathrm{C} / \mathrm{s}\right.$ to $\left.440^{\circ} \mathrm{C}\right)$. Decrease of the temperature at which slower cooling begins results in an occurrence of the martensite. As expected, more martensite was predicted for faster cooling in the first stage.

\subsection{SIMULATIONS OF COOLING OF TUBES}

When the cooling is uniform from all sides the problem becomes symmetrical and all parameters are homogenous around the tube's circumference. Variations of the parameters through the wall thickness only are 

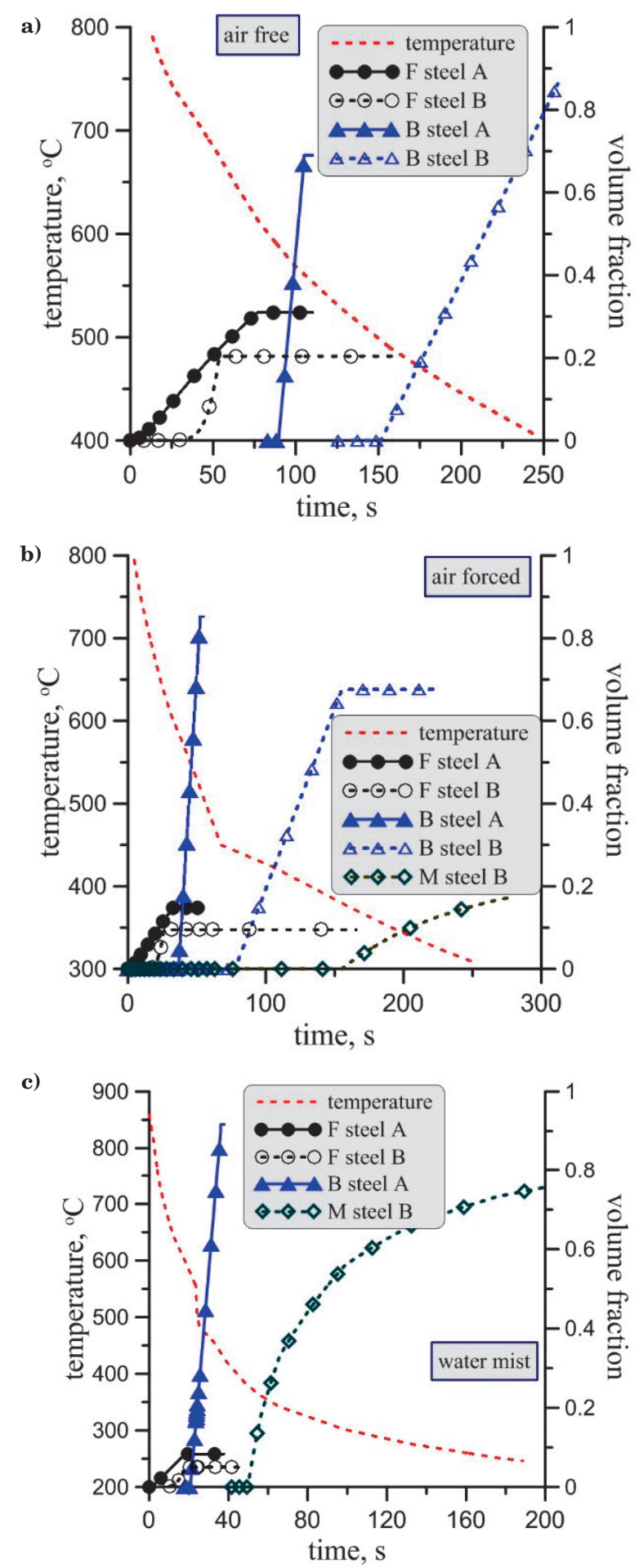

Fig. 8. Kinetics of phase transformations for cooling with the rate of $4^{\circ} \mathrm{C} / \mathrm{s}$ to the temperature of $450^{\circ} \mathrm{C}$ followed by slow cooling $\left(0.5^{\circ} \mathrm{C} / \mathrm{s}\right)$

Rys. 8. Kinetyka przemian fazowych podczas chłodzenia z szybkościa $4^{\circ} \mathrm{C} / \mathrm{s}$ do temperatury $450^{\circ} \mathrm{C}$, po którym następowało chłodzenie z szybkością $0,5^{\circ} \mathrm{C} / \mathrm{s}$

observed. Such uniform cooling problem was considered first. Kinetics of transformation for three cooling schedules presented in section 2.1 was calculated and the results are presented in Figure 8. Austenite grain size adapted in the simulations was $30 \mu \mathrm{m}$. A tube having dimensions $32 \times 4.2 \mathrm{~mm}$ was considered. Results for the centre of the tube wall are presented in Figure 8. Variations of phase volume fractions through the thickness are small. It can be concluded from Figure 8 that transformations are much faster for steel A. More ferrite was obtained for this steel in all considered cooling sequences. Due to delay of ferrite and bainite transformations in steel B caused by higher alloying elements content, martensite was obtained for this steel for pressurised air and water mist cooling.

Following tests were performed to evaluate an influence of the diameter and wall thickness on the phase composition of tubes. Selected plots showing kinetics of transformation for various tube dimensions and various cooling methods are shown in Figure 9. Following four dimensions of tubes were considered: $31 \times 3.6 \mathrm{~mm}$, $32 \times 4.2 \mathrm{~mm}, 38 \times 5.6 \mathrm{~mm}, 51 \times 4.0 \mathrm{~mm}$. All results are summarised in the form of volume fraction of phases in Figure 10.
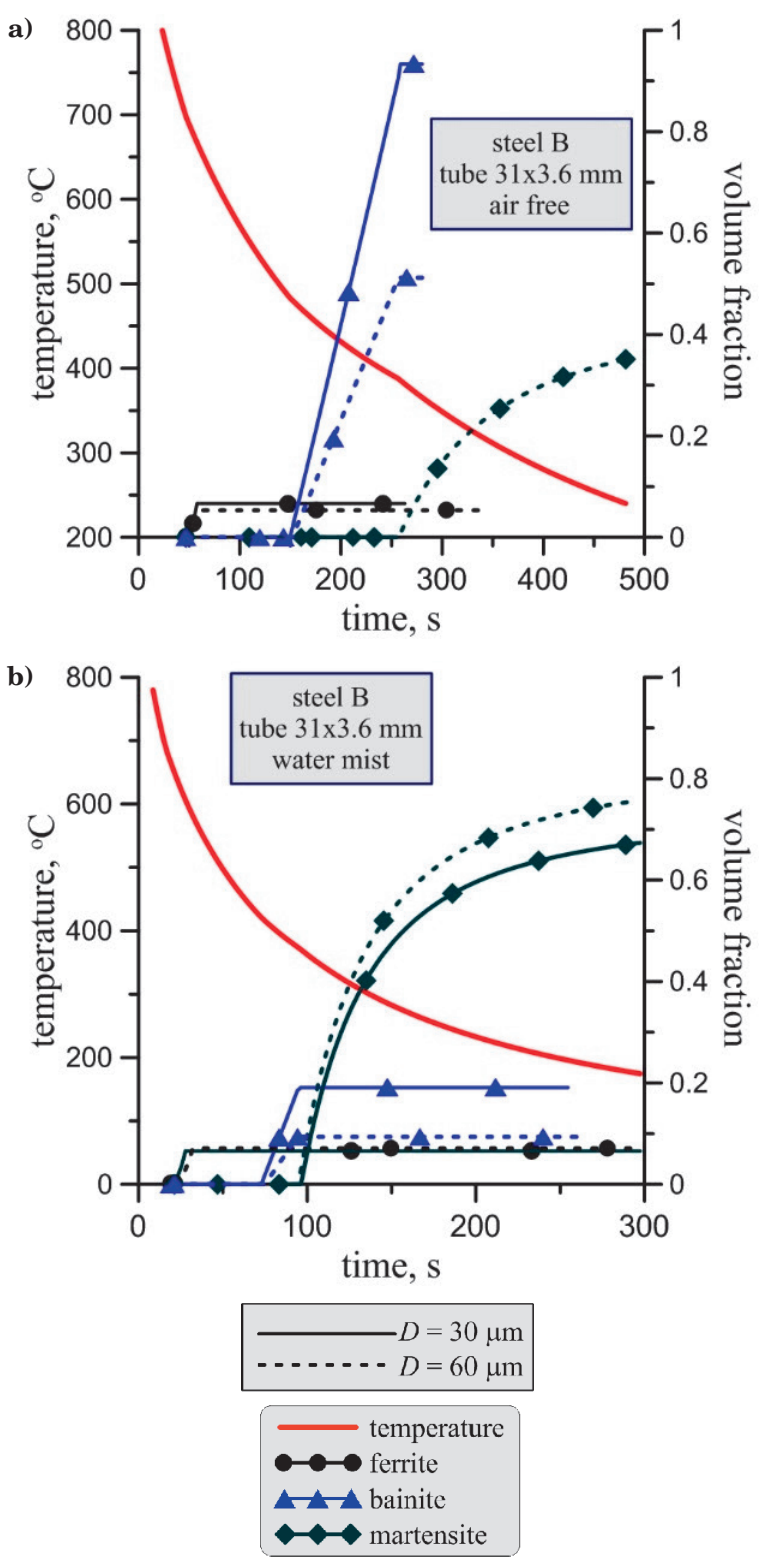

Fig. 9. Kinetics of phase transformations for various tube dimensions, various austenite grain size and various cooling conditions. Meaning of symbols and lines is the same in all plots

Rys. 9. Kinetyka przemian fazowych dla różnych wymiarów rur, różnych wielkości ziarna austenitu i różnych metod chłodzenia. Znaczenie linii i symboli jest takie samo dla wszystkich rysunków 

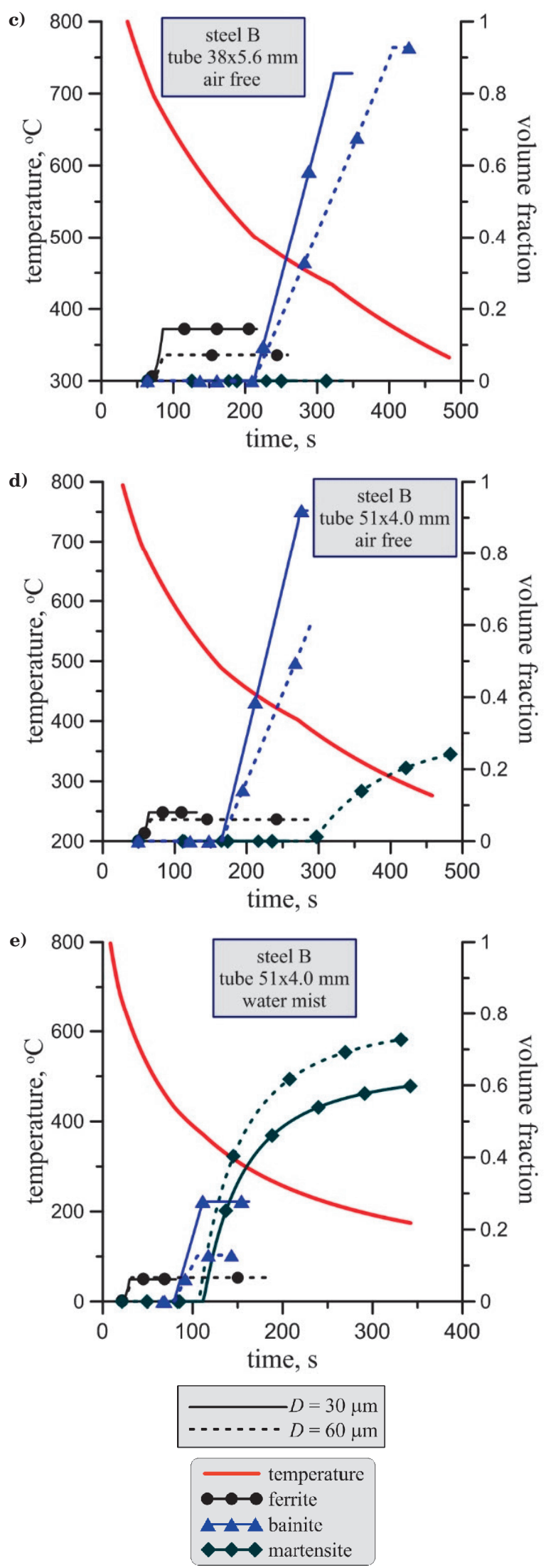

Fig. 9 cont. Kinetics of phase transformations for various tube dimensions, various austenite grain size and various cooling conditions. Meaning of symbols and lines is the same in all plots

Rys. 9 cd. Kinetyka przemian fazowych dla różnych wymiarów rur, różnych wielkości ziarna austenitu i różnych metod chłodzenia. Znaczenie linii i symboli jest takie samo dla wszystkich rysunków
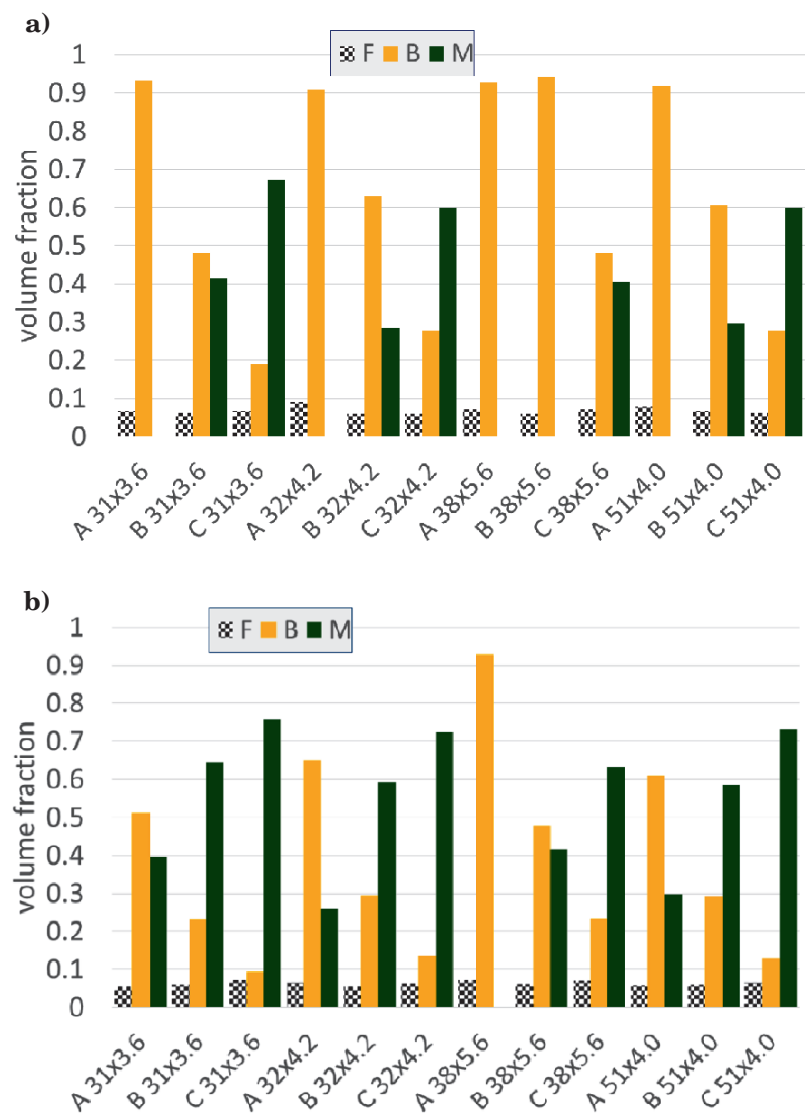

Fig. 10. Calculated volume fractions of microstructural constituents for various tube dimensions and various cooling conditions, grain size $30 \mu \mathrm{m}$ (a) and $60 \mu \mathrm{m}$ (b). (A - cooling in the still air, $\mathrm{B}$ - cooling with the pressurised air, C - cooling with the water mist)

Rys. 10. Obliczone udziały objętościowe składników mikrostruktury dla różnych wymiarów rur i różnych sposobów chłodzenia, wielkość ziarna $30 \mu \mathrm{m}$ (a) i $60 \mu \mathrm{m}$ (b). (A - chłodzenie w spokojnym powietrzu, B - chłodzenie sprężonym powietrzem, C - chłodzenie mgłą wodnopowietrzną)

Comparing obtained results of the simulations, one can see that both increasing the cooling rate and decreasing tube's wall thickness and diameter results in more martensite and less ferrite content in the resulting microstructure. Also, increasing austenite grain size increases the martensite content in the microstructure of the tubes. On the contrary, during cooling with smaller rates, ferrite is the principal microstructure constituent. What is most important, the obtained results show that only small amount of bainite is formed under continuous cooling conditions. Therefore, two-stage cooling considered earlier is a prerequisite for the bainite occurrence in the tubes.

All calculations above were performed assuming uniform cooling of the tube around the circumference. The developed FE code enables also considering nonuniform cooling. To demonstrate this functionality, calculations were repeated assuming cooling by the water mist from the right side only. Figure 11a shows distribution of the temperature after $100 \mathrm{~s}$ of cooling. The variation of the temperature caused slight difference in the bainite volume fraction shown in Figure 11b. Overall difference of $7 \%$ between the two sides of the tube was obtained. 

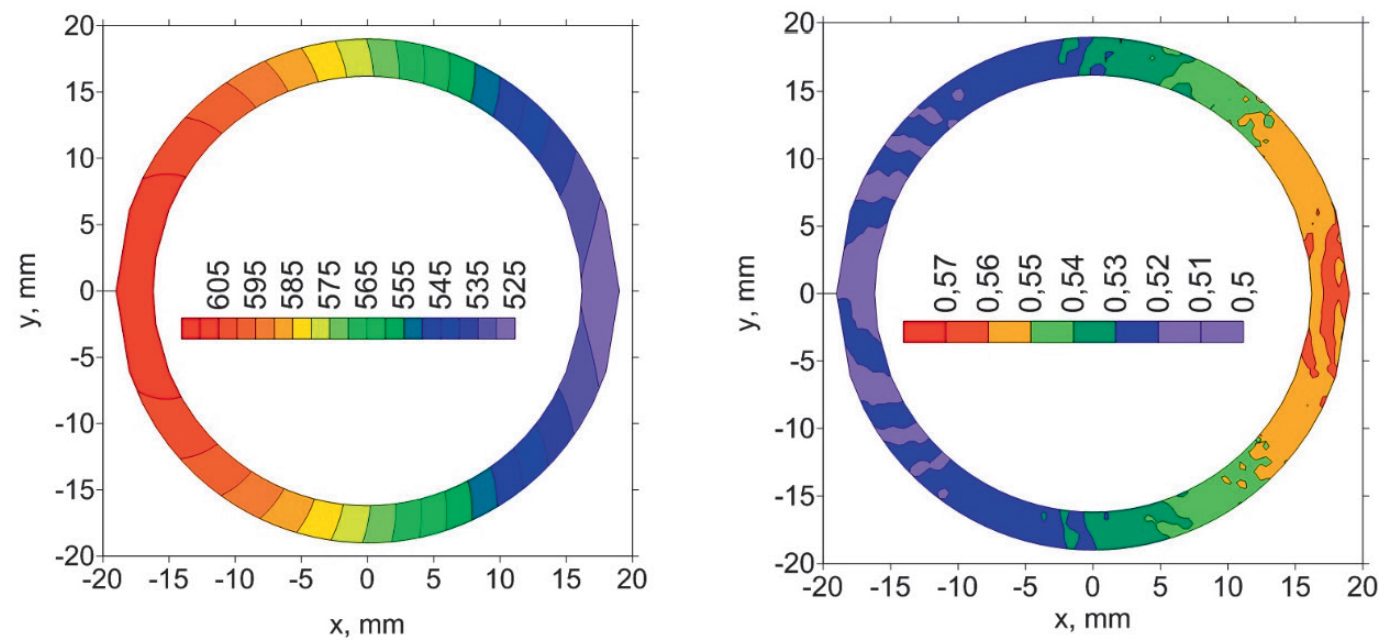

Fig. 11. Calculated temperature distribution (a) and bainite volume fraction (b) in the tube $38 \times 5.6 \mathrm{~mm}$ after $100 \mathrm{~s}$ of cooling, water mist from the right side and still air from the left side

Rys. 11. Obliczony rozkład temperatury (a) i udział objętościowy bainitu (b) w rurze o wymiarach $38 \times 5.6 \mathrm{~mm}$ po $100 \mathrm{~s}$ chłodzenia mgła wodna z prawej strony i w spokojnym powietrzu z lewej strony

\section{CONCLUSIONS}

The complex model describing changes of the temperatures and phase transformations during cooling of tubes was described in the paper. Phase transformation model was identified for the two tube steels. Thermal model was validated by comparison of prediction with the measurements in the laboratory conditions. Numerical tests of the model were performed and following conclusions were drawn:

- Phase composition of the tube steel is strongly sensitive to the cooling variants. Fast cooling to the temperatures range $400-460^{\circ} \mathrm{C}$ followed by slow cooling showed that bainite with some ferrite was obtained for larger temperatures while purely martensitic microstructure was obtained for $400^{\circ} \mathrm{C}$.

- An increase of the austenite grain size slows down ferrite and bainite transformations. In consequence, more martensite was predicted for the tests with larger grain size.
- Calculations performed for the two investigated steels showed that an increase of carbon, silicon and chromium content caused a slowing down the bainite and ferrite transformations.

- Air cooling of tubes resulted in ferrite and some bainite in the microstructure. An increase of the tube diameter and/or tube wall thickness led to some increase of the amount of the ferrite in the microstructure under the same cooling conditions.

- For the investigated tubes dimensions, variations of the phase volume fractions through the thickness of the tube wall were small.

- Asymmetric cooling, water mist from one side and free air from the opposite side, resulted in $7 \%$ difference in the bainite content between the two sides.

\section{Acknowledgements \\ The work performed within the project POIR. 01.01.01-00-0887/17.}

\section{REFERENCES}

[1] H.K.D.H. Bhadeshia. Bainite in steels, $2^{\text {nd }}$ ed., Cambridge: The University Press, 2001.

[2] H.K.D.H Bhadeshia. The lower bainite transformation and the significance of carbide precipitation. Acta Metallurgica, 1980, 28, p. 1103-1114.

[3] N.V. Luzginova, L. Zhao, J. Sietsma. Bainite formation kinetics in high carbon alloyed steel. Materials Science and Engineering A, 2008, 481-482 (1), p. 766-769.

[4] W. Song, U. Prahl, W. Bleck, K. Mukherjee. Phase-field simulations of bainitic phase transformation in $100 \mathrm{Cr} 6$. In: TMS - 140th Annual Meeting and Exhibition. San Diego, CA, USA, 2011, p. 417-425.

[5] A. Sakamoto, K. Yamamoto, K. Okamura, Y. Arai, Y. Serizawa. Water cooling technologies for steel pipe production processes. Nippon Steel \& Sumitomo Metal Technical Report No. 111. 2016. p. 107-112.

[6] R. Kuziak, K. Radwański, K. Perzyński, Ł. Madej, M. Pietrzyk. Validation of material models for bainitic steels used in optimization of manufacturing chain for fasteners. Computer Methods in Materials Science, 2014, 14 (1), p. 37-52.
[7] M. Pietrzyk, Z. Kania, R. Kuziak, Ł. Rauch, J. Kusiak. A simple model for prediction of retained austenite in steel rods after hot rolling and controlled cooling. In: B. Buchmayr (ed.), Proc. XXXV Verformungskundliches Kolloquium. Zauchensee, 2016, p. 56-66.

[8] M. Pietrzyk. Finite element based model of structure development in the hot rolling process. Steel Research International, 1990, 61 (12), p. 603-607.

[9] O.C. Zienkiewicz. Finite element method in thermal problems. In: R.W. Lewis, K. Morgan, O.C. Zienkiewicz (ed.), Heat Transfer. John Wiley \& Sons, 1981, p. 1-25.

[10] J.G. Lenard, M. Pietrzyk, L. Cser. Mathematical and Physical Simulation of the Properties of Hot Rolled Products. Amsterdam: Elsevier Science, 1999.

[11] Z. Malinowski, J.G. Lenard, M.E. Davies. A study of the heattransfer coefficient as a function of temperature and pressure. Journal of Materials Processing Technology, 1994, 41 (2), p. 125-142.

[12] M. Pietrzyk, R. Kuziak. Modelling phase transformations in steel. In: J. Lin, D. Balint, M. Pietrzyk (ed.), Microstructure 
evolution in metal forming processes. Oxford: Woodhead Publishing, 2012, p. 145-179.

[13] M. Pietrzyk, Ł. Madej, Ł. Rauch, D. Szeliga. Computationa Materials Engineering: Achieving high accuracy and efficiency in metals processing simulations. Butterworth-Heinemann, 2015.

[14] B. Donnay, J.C. Herman, V. Leroy, U. Lotter, R. Grossterlinden. Microstructure evolution of C-Mn Steels in the hot deformation process: The STRIPCAM model. In: J.H. Beynon,
P. Ingham, H. Teichert, Waterson K. (ed.), Proceedings of 2nd International Conference Modelling of Metal Rolling Processes. London, 1996, p. 23-35.

[15] E. Scheil. Anlaufzeit der Austenitumwandlung, Archiv für das Eisenhüttenwesen, 1935, 12, p. 565-567.

[16] A.I. Katsamas, G.N. Haidemenopoulos. A semi-empirical model for the evolution of retained austenite via bainitic transformation in multiphase TRIP steels. Steel Research International, 2008, 79, p. 875-884. 